\title{
Space Consolidation for Fishing Settlement in Mariso District, Makassar City with Space Syntax
}

\author{
Andi Andre Pratama Putra ${ }^{1}$, Ardhya \\ Nareswari'2, Budi Prayitno ${ }^{2}$ \\ ${ }^{1}$ Student, Master of Architecture Engineering, Universitas Gadjah Mada \\ ${ }^{2}$ Lecturer, Departement of Architecture and Planning Engineering, \\ Universitas Gadjah Mada
}

\author{
Article History \\ Received : 20 September 2018 \\ Accepted : 01 August 2019 \\ Published : 01 April 2019
}

\begin{abstract}
This paper discusses the development and changes in space that occur in the fishermen's area of Panambungan fisheries in Mariso sub-district, along with the changes in space that occur as a result of reclamation activities and changes in spatial patterns around the fishing settlement area. Changes in the settlement's spatial pattern show a trend of discrepancies between urban developments and the physical conditions of fishing settlement that can cause a decline in regional values. The study aims to get an overview of the current condition of the fishing settlement of Mariso and their changes based on the 2015-2034 spatial plan of Makassar city, and the consolidated directives that can be done. The results of this study are expected to be an input or a recommendation for Mariso fishing settlement in particular and the fishing settlement in Indonesia in general. The analysis process uses quantitative syntactic analysis with the help of DepthmapX computer software with descriptive quantitative method that is focused on consolidating the Mariso connection fisherman settlement. The results of the study show that the development of the city shows that the Mariso fisherman settlement spatial configuration based on the 2015-2034 Makassar City spatial plan has a better value of space analysis (integration, connectivity, mean of depth, choice and intelligibility), but there is a mismatch of physical spatial functions and patterns with existing fishing settlement. This is indicated by the occurrence of economic activity in the area (interaction), in which there is a change in space that does not support fisherman activities.
\end{abstract}

Keywords: fishing settlement, space syntax, space integration

\section{Introduction}

The residential area in Mariso is a densely populated slum area in which the inhabitants are mainly fishermen. Mariso district itself is recorded as a region with the second highest population density in Makassar City. The existence of limited residential land causes these settlements to become very dense and unorganized. The dense settlements are unfortunately not accompanied by adequate

Correspondence: Andi Andre Pratama Putra

Student of the Master of Architecture Engineering, Gadjah Mada University

E-mail: aandrepratamap@gmail.com facilities and infrastructure. Poor drainage and solid waste management result in poor condition of the settlement. In addition, dense settlement also causes the streets to be very narrow with many small alleys. With an area that is located close to the coast, many residents in this region depend for their livelihood by working as fishermen. However, it is currently threatened by the reclamation in the Tanjung Bunga Region and the Center Point of Indonesia which closes the fishermen's access to the coast. This certainly can cause the fishermen to lose their jobs due to increased mileage and uncertain catch. If the fishermen lose their jobs, the condition of 
settlement may worsen. With all the existing limitations, they can only live and occupy homes with limited eligibility conditions in terms of construction, materials and other facilities and infrastructure to support their daily lives. With the decline in the number of fishermen in Mariso, fish traders in the TPI Rajawali fish auction site mostly buy fish from other areas, such as Sinjai, Bulukumba, and Takalar.

Table 1. The number of fishermen in Panambungan

\begin{tabular}{|c|c|c|}
\hline $\begin{array}{c}\text { Type of } \\
\text { Fishermen }\end{array}$ & 2008 & 2017 \\
\hline Seashell Hunters & 40 people & 0 people \\
\hline Fishermen & 43 people & 42 people \\
\hline Total & 83 people & 42 people \\
\hline
\end{tabular}

Figure 1 a. Map of Mariso in 2000, b. Map of Mariso in 2017, c. Mariso based on the 2015-2030 Makassar Spatial Plan, d. Mariso Fishing Settlement

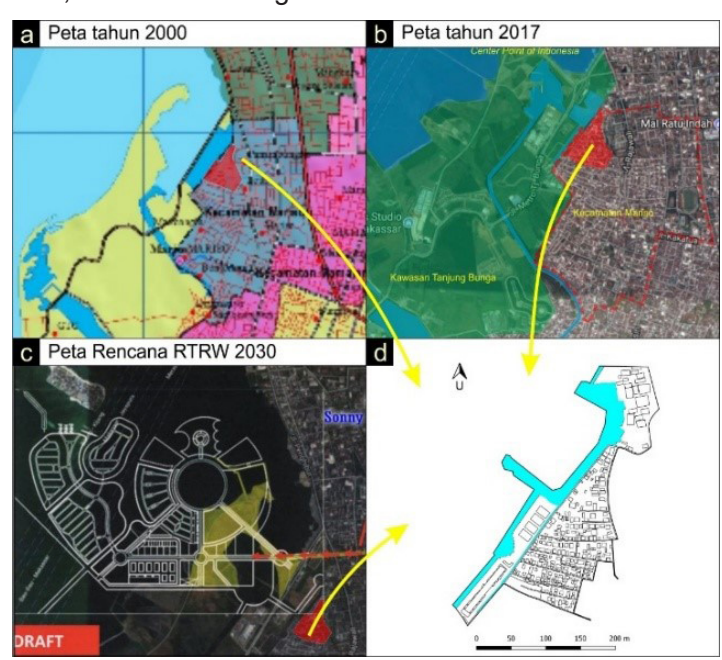

Each space is related to other spaces, and if there is a change in the space system, it will have an impact on the overall space structure system (Hillier, Space is the machine : A Configurational Theory of Architecture, 2007). Changes in space that occur around the reclamation area naturally affects the fishing settlement in Mariso. This study will analyze changes in the existing space based on the Makassar City Spatial Plan in 2030. To analyze the overall regional space performance, space syntax analysis, which was first suggested by Hiller and Hanson (1984) in his book Social Logic of Space, is used.

\section{Problem of Analysis}

The Mariso fishing settlement area has an unplanned configuration of space which results in a separate residential area from the regional space system. In addition, the development of the Tanjung Bunga area and the Center Point of Indonesia reclamation project in the Makassar City coastal area have led to changes in the waterfront area of fishing settlement in Mariso District. Therefore, it is important that the impact of the configuration changes that occur on the fishing settlement be examined.

\section{Research Questions}

What is the current analysis value of Mariso fishing settlement space based on space syntax? How does Mariso fishing settlement space change after the configuration of the street space based on the 2015-2030 Makassar City spatial plan based on space syntax? How does Mariso fishing settlement space change after consolidation based on space syntax?

\section{Literature Review}

\section{Urban Space Consolidation}

Urban space consolidation is a policy measure that addresses the problem of urban sprawl. The latter can described as "the process in which the spread of development across the landscape far outpaces population growth." The landscape sprawl has four dimensions, i.e. a population that is widely dispersed in lowdensity development; rigidly separated homes, shops, and workplaces; a network of streets marked by huge blocks and poor access; and a lack of well-defined, thriving activity centers, such as downtowns and town centers"(Ewing et al, 2002:3).

According to Prayitno (2012) space consolidation is a step towards improving an area that has been degraded by restructuring and strengthening the space in the region. The consolidation steps that can be applied include: a. Mapping regional potential and vulnerability b. Analyze regional results and vulnerabilities c. Solving problems with the concept of regional character

In the effort to consolidate urban space, Hillier (2014) introduces space syntax as a theory as well as a method. Essentially, space syntax consists of the following procedures:

a. Build a model of the current site and its 
context, usually the whole city

b. Test the model against existing movement flows and land use patterns

c. Use the verified model to test out designs by inserting the designs into the model and rerunning the analysis

d. Suggest new design ideas from the analysis

The space consolidation referred to in this paper which will be explained further in the space syntax literature review.

\section{Fishing Settlement}

Kusnadi (in Rusli 2000), states that the shape and pattern of fishing settlement spaces are influenced by work and life activities that are in accordance with the coastal potential. Juhana (2001) states that generally fishermen's residential spaces grow linearly following the coastline.

Rachmawati (2017) states that to see the physical characteristics of fishing settlement, there are three indicators, namely the completeness of facilities and infrastructure, the quality of residential buildings and the quality of the environment of fishing settlement.

Rusli (2016) stated that the development of fishing settlement space consists of 5 aspects, namely the function of the house, economy and tourism, facilities and infrastructure, the cultural value system of trade, and industry activity patterns. The function of the fishing settlement space serves in a pleasant architectural, aesthetic, comfortable and beautiful context. The diverse functions of the settlement space mean that there are interrelated relationships, in which various activities can be carried out in closed spaces, open spaces, and in the form of integrated street facilities and infrastructure networks in the settlement space. This physical, aesthetic and comfort functions will be realized in the form of an ideal settlement space. In its development, the function of fishing settlement space is influenced by social, cultural and economic activities. The ideal concept of a fishing settlement is a settlement space that is in accordance with a set of principles, namely cultural diversity and interaction without causing conflict in the use of space for fishing settlement. From the concept of integration of fishing settlement, Rusli (2016) states that the availability of facilities will support the concept of residential space integration with coastal ecotourism functionally.

From the summary of previous theories, the ideal urban fishing settlement can be achieved with complete facilities and infrastructure that can support life as a fisherman. The residential buildings should also be comfortable and orderly, have a low level of waste pollution, a good disaster mitigation plan, as well as well-integrated infrastructure and supporting facilities for fishermen's economy that are in accordance with the forms of social, economic and cultural activities of the people.

\section{Space Syntax}

Hillier and Hansen (1984) wrote The Social Logic of Space and put forward a new theory of space as a social aspect of life. Since then, the theory has developed into an extensive research program on the nature of space, building functions and cities.

To understand space syntax, one must begin with a certain description of the spatial architecture of buildings and cities. In space syntax, spaces are understood as voids (streets, squares, rooms, parks, etc.). Voids are defined by obstructions that might either constrain access and/or occlude vision (such as walls, fences, furniture, partitions and other imped-iments). Buildings are composed of a series of spaces; each space has at least one link to other spaces. The structural properties that comprise these spaces and links might have an embedded social meaning that has implications on the overall behavior of human habitat.

The same description might also apply on an urban scale. Cities are aggregates of buildings held together by a network of spaces flowing in-between the blocks. This network connects a set of street spaces that form together a discrete struc 7 ture. The structure is the optimum result of shortest paths from all origins to all destinations in the spatial system. It is what holds it all together. It has an archi-tecture, and by this we mean a certain geometry and a certain topology,that is, a certain pattern of connections (Al_Sayed K, 2014).

By using a computer software with output in the form of graphic representation, space syntax as an analysis tool can be used by researchers and designers in various fields of application in architecture and urban design (Hillier, Space 
is the machine : A Configurational Theory of Architecture, 2007).

Configuration can be understood as a relationship or relationship caused by the simultaneous co-presence of a third element, which may also be caused by other interconnected elements (Hillier, 1997 in Darjosanjoto, 2005).

There are two principles in space configuration:

a. Changing one element in a configuration results in changes not only in the character of the other configuration elements, but also in all the elements that make up the unity.

b. All of the configuration elements in the unity can change with the change of one element, meaning that the change does not cancel the relationship or linkages between the elements but instead presents a variety of configuration element characteristics (Hillier, 1996 in Darjosanjoto, 2005).

\section{Research Methods}

This study uses a descriptive and simulation research framework. Descriptive research is used to express the data and findings accurately and systematically. Meanwhile, simulation and modeling using computers are used to solve and or answer a real modeling (Darjosanjoto, 2005 15-27).

The focus of this research is consolidation related to changes in Mariso fishing settlement space which is separated (segregated) from other spaces. For this reason, it is necessary to map the fishing settlement space as well as analyze the changes of living conditions using space syntax analysis. Observations are done on the physical condition of the fishing settlement area, including the completeness of facilities and infrastructure, the building quality, and the environmental quality. In the analysis of space syntax simulation, observation is done on the human movement in the area and the syntactic analysis of space.

The space syntax analysis technique is based on observing the residential environment through natural movement, which is related to the proportion of pedestrian steps in various forms of grid layout determined by the arrangement of the outline (grid).
Representations of the elements forming the space configuration are displayed in axial map and convex map.

On an urban scale, Space Syntax regards movement as the generic function of street spaces (Hillier, Penn, Hanson, Grajewski, \& $\mathrm{Xu}, 1993)$ and hence reduces these spaces to the longest accessible lines that cover all convex spaces in a map, i.e. the axial lines or "lines of sight." These elementary components and their adjacency relationships can be repre sented by a network (nodes or vertices of a GA morphological graph). The graph will consist of two sets of information; graph vertices (representing axial lines) $\mathrm{VA}=$ $\{v A 1, v A 2, \ldots v A n\}$, and a set of lines $L I=\{\| 1$, II2, ... IIL $\}$. Each line in the graph represents an intersection between two axial lines (two vertices) in the spatial network. Spatia I adjacency is the fundamental relationship that characterizes how structures might be configured in a spatial layout. Two spaces, i and $\mathrm{j}$, are considered as adjacent in the dual GA graph when it is possible to access one space directly from another, without having to pass through intervening spaces. In graph theory, GA graph is regarded as non-planar dual graph. It is non-directional in that:

$$
I_{k}=\left(v_{i}, v_{j}\right)=\left(v_{j}, v_{i}\right)
$$

In axial representations, depth is identified as the change in direction between one axial line and another. Depth is topological; in other words, it has no geometric value. Axial maps are fundamental syntactic representations theoretically, because they reflect many structural properties of urban street networksi.e. line lengths, intelligibility and synergy. Integration of settlement space within the area can be measured using space syntax, namely: integration, connectivity, mean of depth, choice and intelligibility (Al_Sayed K, 2014). 
Table 2. Research Criteria

\begin{tabular}{ll}
\hline \multicolumn{1}{c}{ Variable } & \multicolumn{1}{c}{ Indicator } \\
\hline Facilities and Infrastructure & The completeness and quality of facilities and infrastructure. \\
Building Quality & $\begin{array}{l}\text { Building materials } \\
\text { Building typology } \\
\text { Land area } \\
\text { Legal status }\end{array}$ \\
Environmental Quality & $\begin{array}{l}\text { The level of environmental pollution } \\
\text { Frequency of disaster }\end{array}$ \\
Activity (Human Movement) & Natural movement (gate count) \\
Fishing Settlement Integration & Integration, connectivity, mean of depth, choice and intelligibility \\
\hline
\end{tabular}

\section{Results and Discussion}

\section{Quality of Facilities and Infrastructure}

Table 3. Details on Facilities and Infrastructure

\begin{tabular}{|c|c|}
\hline Variable & Actual Condition in the Field \\
\hline Street & $\begin{array}{l}\text { - Street width of } 2.5 m-3 m \\
\text { - Uneven street } \\
\text { - Buildings directly adjacent to the street } \\
\text { - Deadlock area }\end{array}$ \\
\hline Clean water supply & $\begin{array}{l}\text { - PDAM (Regional Water Utility Service) clean water is distributed evenly in the fishing } \\
\text { settlement. } \\
\text { - Brackish ground water }\end{array}$ \\
\hline Waste system & $\begin{array}{l}\text { - There is no temporary landfill at the domestic and regional level. } \\
\text { - Waste is not sorted (organic and inorganic). } \\
\text { - There is no independent waste management system by the community to overcome the } \\
\text { amount of solid waste that exist. }\end{array}$ \\
\hline Drainage & $\begin{array}{l}\text { - Clogged with garbage } \\
\text { - Not closed } \\
\text { - Does not flow } \\
\text { - Shallow }\end{array}$ \\
\hline Wastewater & $\begin{array}{l}\text { - Waste is directly discharged into the sewage that is connected to the sea, causing smells } \\
\text { and damages to the environment. } \\
\text { - There is no processing for fish waste. }\end{array}$ \\
\hline Fish auction place & $\begin{array}{l}\text { - Good condition although still traditional } \\
\text { - Only markets raw catches }\end{array}$ \\
\hline Fish drying place & $\begin{array}{l}\text { - Still uses makeshift tools } \\
\text { - The dried fish is only consumed by the fishermen themselves (not for sale). }\end{array}$ \\
\hline Boat mooring & $\begin{array}{l}\text { - Narrowing from year to year } \\
\text { - Only small vessels can lean on boat moorings due to the lack of a mooring area. }\end{array}$ \\
\hline Fish landing center & - No longer relies on the catch of local fishermen \\
\hline Boat workshop & - No boat repair shop at the observation site \\
\hline Filling station & $\begin{array}{l}\text { - Located in areas accessible by fishermen } \\
\text { - A number of fishermen still do not have a fisherman card. }\end{array}$ \\
\hline
\end{tabular}


Space Consolidation for Fishing Settlement in Mariso District, Makassar City with Space Syntax

Andi Andre Pratama Putra, Ardhya Nareswari, Budi Prayitno

75

Figure 2. Spatial Structure
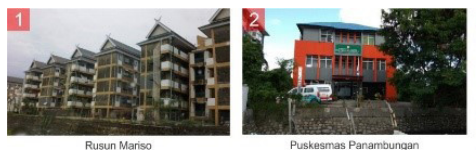

û

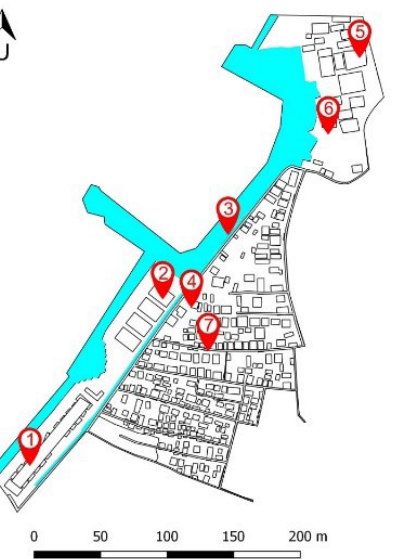

Building Quality

Figure 3. Fishermen's houses

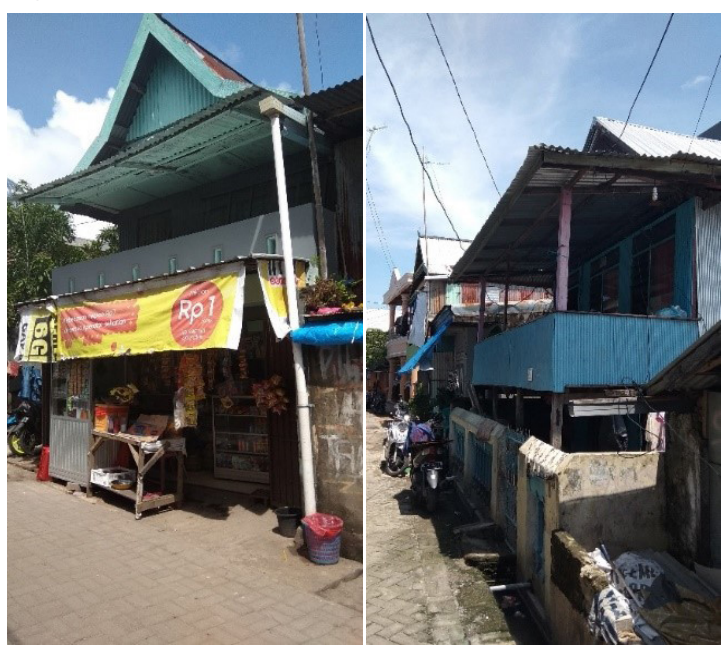

Most of the residents' houses use semipermanent brick and wood material with characteristics of a Bugis-Makassar traditional house in which the floor is raised. However, as a result of the shrinking number of fishermen and the cessation of fishing activities in the past few years, the form of houses in the fishing settlement has undergone a change. For instance, the space below the house (ground floor), which typically does not have partitions or walls as it is used for preparing nets and fishing equipment or repairing boats, is converted to function as a living room, a small shop, etc. by adding walls.

\section{Environmental Quality}

Figure 4. Map of Regional Tidal Waves

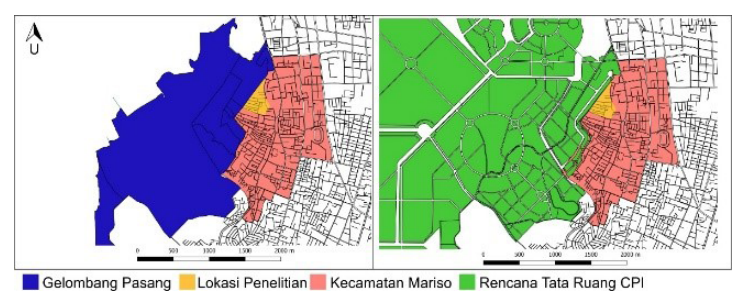

From the results of the interviews that have been conducted, this region has never experienced flooding before. However, the reclamation activities in the coastal area have caused tidal flooding as high as adult's calves in the area during the rainy season. This is exacerbated by poor drainage condition in the region and the littering habit of the residents. This vulnerability will threaten the assets of life, society, properties and infrastructure, as well as the social, cultural and political activities, and the environment.

\section{Convex Map Representation of Existing Area}

Figure 5. Convex map representation of human movement within the area

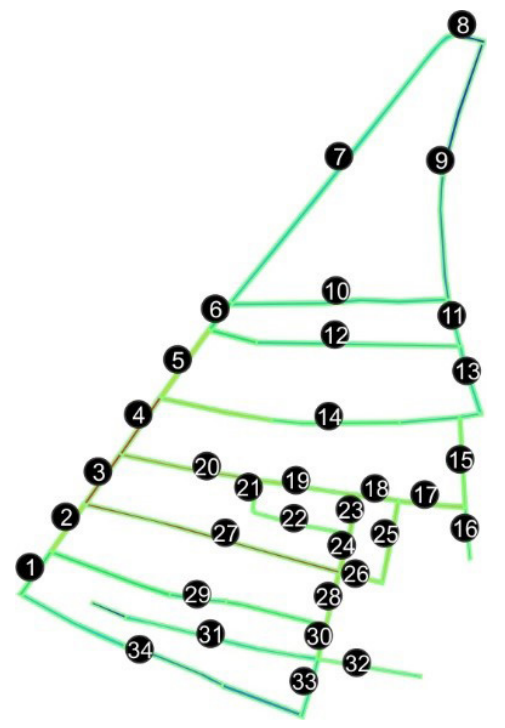

Based on the gate count observations as displayed in tables and convex representations, the total human movement in the area is highest in the afternoon with a total number of 613 , followed by noon with a total of 512 movements and during the day with a total of 416 movements. Human movement is the lowest in daytime due to the high temperature around the area, especially considering the 
coastal location of the area.

Human movement using motorcycles as vehicle is the highest, followed by the movement of adult and children pedestrians with a total number of 297, 237 and 308, respectively. This shows that the fishermen communities of Mariso tend to use motorcycles for mobility purposes. The number of human movement using bicycles, rickshaws and cars is categorized as low. Due to their lack of practicality and inefficiency, bicycles and pedicabs are rarely used by Mariso fishermen. As for cars, apart from being expensive, the narrow street condition with a width of only between 2-3.5 m results in very little human movement using cars in the area.

Gate 30 has the highest number of human movements in the area with a total of 111, followed by Gate 34 with a total of 96 human movements. This high movement may be caused by the fact that the street is wider than other streets in the area. In addition, this street space connects other street spaces within the area, resulting in a higher connectivity value compared to other streets in the area. Gate 1, $2,3,4,5$ and 6 also have the same properties as Gate 30 and 34 , but at the time of the measurement, the street space underwent a construction, hence causing low human movement at the gates.

The gate with the lowest number of moves is Gate 21 with only 9 human movements. In addition to the amount of displacement of space (many bends), this can be caused by the facts that the street space has a very narrow width, and that the location of the street space has a high depth. Space users tend to use other street spaces with wider street conditions and less space transfer in using space.

Table 4. The results of convex map analysis

\section{Visual Graph Analysis Representation of Existing Area}

Figure 6. Visual Graph Analysis Representation

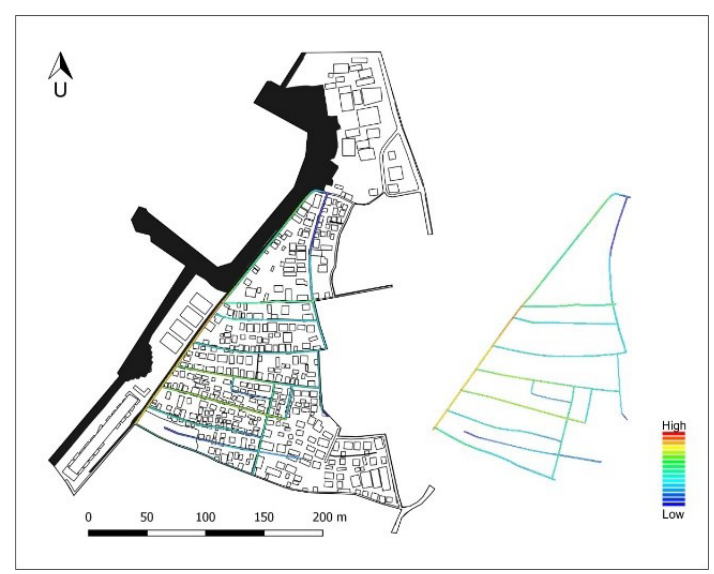

Based on the VGA representation above, the red to orange area is located in street spaces $1,2,3,4,5$ and 6 , thus indicating that this area has good visual integration qualities. Apart from that, this street space has a larger width than other street spaces which is equal to 3.5 $\mathrm{m}$, as well as a lower depth compared to other spaces in the space system.

The area with dark purple is street space 9, which is a dead-end area. This emphasizes that dead-end areas are those with low integration levels and low connectivity with other spaces, causing users to have difficulty understanding the area as a whole. Moreover, street space 9 has a curved shape, which makes the users' visual range more limited compared to a straight street space. Density is also a factor that causes the visual quality in the fishing settlement area to be limited.

Table 5. The results of visual graph analysis

\begin{tabular}{llll}
\hline Attribute & Minimum & Average & Maximum \\
\hline $\begin{array}{l}\text { Connectivity } \\
\begin{array}{l}\text { Point First } \\
\text { Moment }\end{array}\end{array}$ & 26 & 461.748 & 1865 \\
$\begin{array}{l}\text { Point Second } \\
\text { Moment }\end{array}$ & 911 & $3.47745 \mathrm{e}+006$ & $3.5892 \mathrm{e}+007$ \\
Visual Integration & 2.31703 & 4.33232 & 7.50081 \\
Visual Step depth & 0 & 2.64896 & 5 \\
\hline
\end{tabular}


Space Consolidation for Fishing Settlement in Mariso District, Makassar City with Space Syntax

Andi Andre Pratama Putra, Ardhya Nareswari, Budi Prayitno

77

\section{Axial Map Representations Configurational Changes}

Figure 7. Axial map representation: Integration of Mariso District globally $(R=n)$

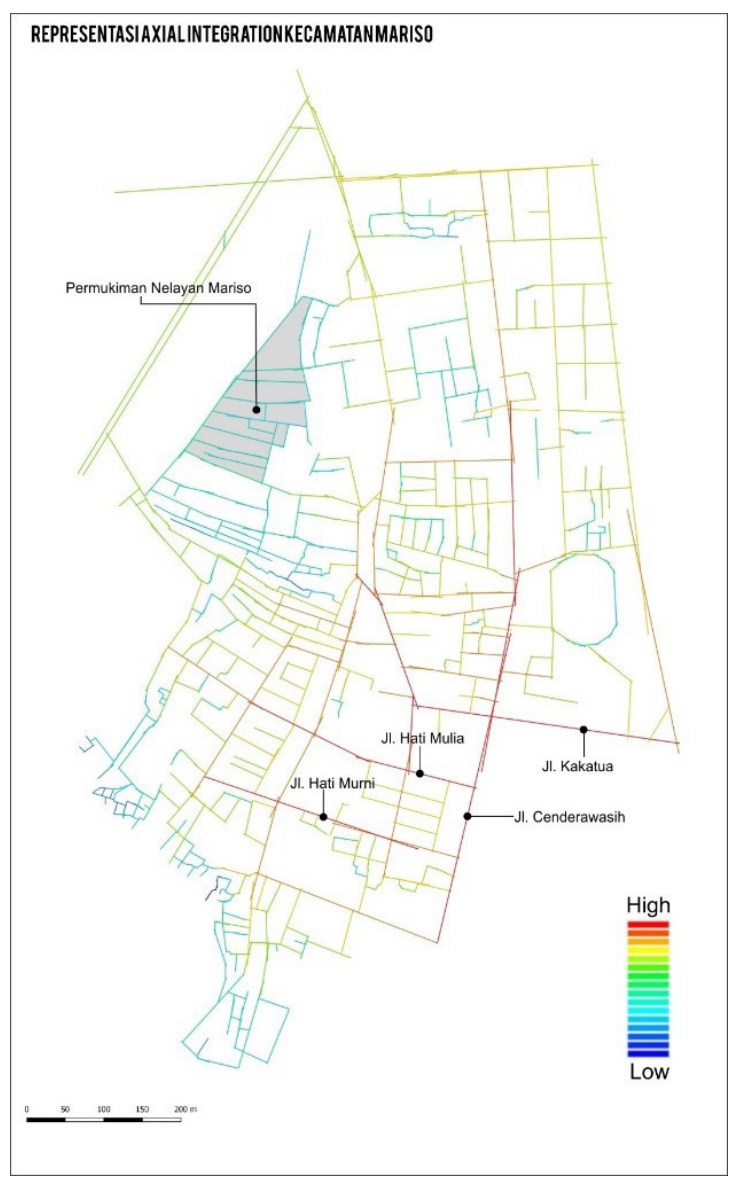

Table 6. The results of analysis in Mariso

\begin{tabular}{ccccc}
\hline \multirow{2}{*}{ Attribute } & & Global & & $\begin{array}{c}\text { Mariso } \\
\text { settlement }\end{array}$ \\
\cline { 2 - 5 } & Minimum & Average & Maximum & Average \\
\hline $\begin{array}{c}\text { Integration } \\
\text { Connec- } \\
\text { tivity }\end{array}$ & 0.344061 & 0.820522 & 1.31112 & 0.665185 \\
$\begin{array}{c}\text { Mean of } \\
\text { Depth } \\
\text { Choice }\end{array}$ & 1 & 2.9494 & 15 & 2.69643 \\
Intelligibility & 0 & 5900.85 & 120859 & 2833.5. \\
\hline
\end{tabular}

of Figure 8 Axial map representation: Integration of Mariso District + Center Point of Indonesia globally $(R=n)$

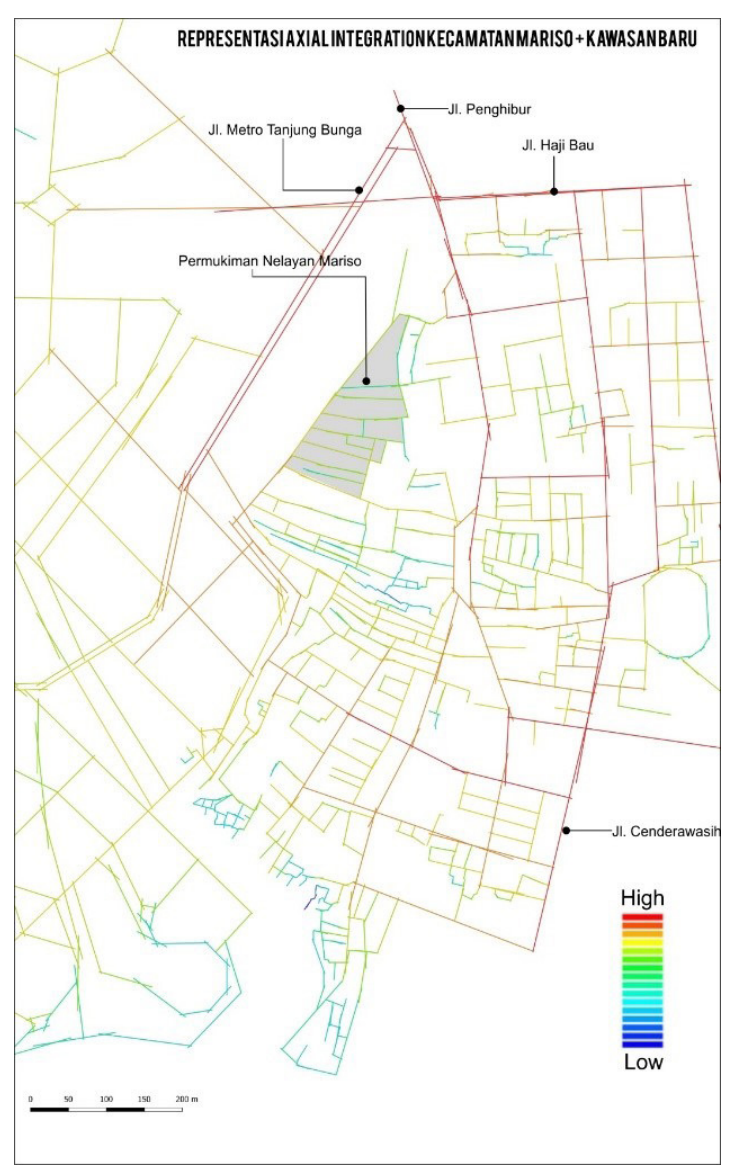

Table 7. The results of analysis with configurational changes based on Makassar spatial plan 2015-2030

\begin{tabular}{ccccc}
\hline \multirow{2}{*}{ Attribute } & \multicolumn{3}{c}{ Global } & $\begin{array}{c}\text { Mariso } \\
\text { settlement }\end{array}$ \\
\cline { 2 - 5 } & Minimum & Average & Maximum & Average \\
\hline Integration & 0.325882 & 0.688417 & 0.997506 & 0.700557 \\
Connectivity & 1 & 3.04578 & 19 & 2.84375 \\
Mean of & 8.38595 & 12.179 & 23.6079 & 11.2735. \\
Depth & & & & \\
Choice & 0 & 10977.8 & 199051 & 5071.03 \\
Intelligibility & & 0.403749 & & 0.76900
\end{tabular}

\section{Discussion}

It must be noted that as Mariso fishing settlement is a work-based settlement, there are economic activities therein. In settlement areas, the results of low connectivity analysis and high mean of depth in these settlements are very reasonable. It would be very wrong if this fishing settlement has a high connectivity, a low mean of depth, and serves as a hub or center in the space system. The concern is to increase the value of integration and choice in areas that have regional economic 
activities because these areas need to be easily understood in terms of their position in the system of integration (integration), and have a choice (choice) which is at least not much different from the value of integration and average choice of the overall system space.

The pattern of mass (buildings) and open void (street space) of an area can affect the value of a regional space. Mariso fishing settlement, with a high mass density and irregular growth, forms a street space that is very narrow and a building that is dense with the street body. The density and orientation of the buildings are not directed and the streets are very narrow. As a result, there are some streets that have very low visual graph analysis values. This can also trigger the occurrence of dead-end street spaces which are not connected with other spaces. A deadlock is only connected to one other space and can cause impurity or loss in the area, hence causing connectivity, integration and clarity of space in the region to be low.

Based on the results of the analysis of the existing conditions, it can be concluded that the Mariso fishing settlement has a low spatial analysis value. The low value of integration and choice causes the fishing settlement area to have a low flow path, in addition to the decline in the value of the area and socioeconomic potential. In the analysis of changes in spatial configuration in accordance with the Makassar City spatial plan, it was found that the fisherman settlement of Mariso experienced an improvement in the value of space. However, the improvement in the value of integration is more due to the closeness of the area with the settlement function to the new settlement area which has a higher value of integration. As a result, the average value of settlement areas is also lower than the overall space system, which is higher compared to the area with the residential function.

Furthermore, consolidation can be done by trying to increase the value of integration and choice in public areas with economic activities by adding street segments that connect the area with streets that have high intensity of use and integration value with fishing settlement areas (additional linkage).

This configuration change is done by taking into account the physical condition of the space by considering that a change in configuration is possible. Improvements were also made by connecting what was formerly a dead-end with other street spaces so that the space in residential areas became clearer.

After adding lines that connect the Mariso fishing settlement area with the economic function, the value of integration and choice of the fishing settlement area is better and higher than the average of the whole area in the space system. This consolidation is also in accordance with the ideal characteristics of fishing settlement where areas with economic functions have a high level of connectivity.

Figure 9. Axial map representation of Mariso and Center Point of Indonesia that have been reconstructed $(R=n)$

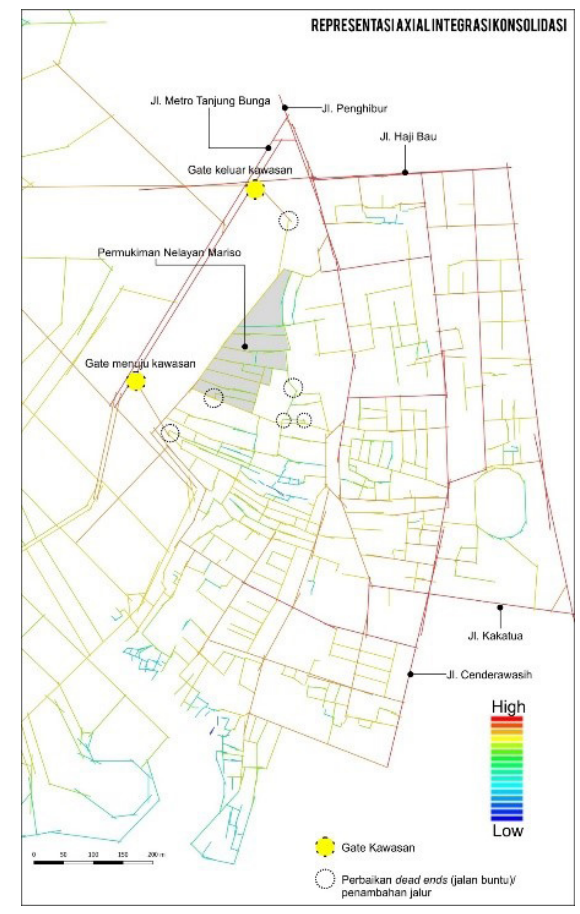

Table 8. Results of the analysis on reconstructed street space in Mariso fishermen's settlement

\begin{tabular}{|c|c|c|c|c|}
\hline \multirow{2}{*}{ Attribute } & \multicolumn{3}{|c|}{ Global } & \multirow{2}{*}{$\begin{array}{c}\begin{array}{c}\text { Mariso } \\
\text { settle- } \\
\text { ment }\end{array} \\
\text { Average }\end{array}$} \\
\hline & Minimum & Average & Maximum & \\
\hline Integration & 0.3266 & 0.694439 & 1.00666 & 0.74959 \\
\hline Connectivity & 1 & 3.06383 & 19 & 3.14 \\
\hline $\begin{array}{l}\text { Mean of } \\
\text { Depth }\end{array}$ & 8.32454 & 12.0949 & 23.5761 & 10.9246 \\
\hline Choice & 0 & 10.939 .5 & 200014 & 10151.3 \\
\hline Intelligibility & & 0.402137 & & 0.77496 \\
\hline
\end{tabular}




\section{Conclusion}

Based on the results of the analysis of the existing conditions, it can be concluded that the Mariso fishing settlement has a low value of space analysis. The low integration and choice values cause the fishing settlement areas to have a low flow of human movement, as well as a decrease in regional values and socioeconomic potential. In the analysis of changes in space configuration in accordance with the spatial plan of Makassar City, it was found that Mariso fishing settlement experienced an improvement in the value of space. However, the improvement of the integration value is more due to the proximity of the settlement function area to new settlement areas with a higher integration value. As a result, the average choice of residential areas is still lower than the overall space system. After the addition of lines connecting the Mariso fishermen's residential area with the economic function, the value of integration and choice of fishermen's residential areas becomes better and higher than the overall area average in the space system. This consolidation is also in accordance with the ideal characteristics of fishing settlements where areas with economic functions have a higher level of connectivity compared to areas with residential functions.

\section{References}

Al_Sayed K, T. A. (2014). Space Syntax Methodology (4th Edition). London: Bartlett School of Architecture UCL.

Biang, F. D. (2008). Dampak Pembangunan Jalan Metro Tanjung Bunga terhadap Komunitas Nelayan di Kota Makassar. Masters Thesis. Universitas Diponegoro.

Darjosanjoto, E. T. (2005). "Kembang Jepun": Jalan Dominan Kota Surabaya. Dimensi Teknik Arsitektur Vol. 33, 143-152.

Ewing, R. P. (2014, April). Measuring Sprawl and Its Impact. Retrieved from Smart Growth Amrerica: http://.smartgrowthamerica. org/research/measuring-sprawl-and-itsimpact/,p.3

Hillier, B. (2007, June 6). Space is the machine : A Configurational Theory of Architecture. Retrieved from University College London: http://discovery.ucl.ac.uk/3881/1/SITM.pdf

Hillier, B. (2014, July 6). Space Syntax as a Theory : as Well as a Method. Retrieved from ISUF 21st International Seminar of
Urban Form: isuf2014.fe.up.pt/Hillier.pdf

Hillier, B., \& Hanson, J. (1984). The Social Logic of Space. Cambridge: Cambridge University Press.

Hillier, B., Penn, A., Hanson, J., Grajewski, T., \& Xu, J. (1993). Natural Movement : or configuration an attraction in urban pedestrian movement. Environment and Planning B : Planning Design (pp. 29-66). London: Univercity College London.

Juhana. (2001). Arsitektur Dalam Masyarakat, Pengaruh Bentukan Arsitektur dan Iklim Terhadap Kenyamanan Thermal Rumah Tinggal Suku Bajo di Wilayah Pesisir Bajoe Kabupaten Bone Sulawesi Selatan. Masters Thesis. Universitas Diponegoro. Semarang: Bendera.

Prayitno, B. (2012). Kampong Upgrading And Greening - Enabling and Learning Processes for Consolidation-based Urban Settlement Redevelopment. Yogyakarta: Departement of Architecture and Planning, Faculty of Engineering, Universitas Gadjah Mada.

Rachmawati, F. (2017). Konsep Pengembangan Kawasan Permukiman Nelayandi Kecamatan Brondong Kabupaten Lamongan Melalui Pendekatan Sustainable Coastal Development. Surabaya: Department of Architecture Faculty of Civil and Planning Engineering, Institut Teknologi Sepuluh Nopember.

Rusli. (2016). Integrasi Ruang Permukiman Nelayan dengan Ekowisata Pesisir di Donggala Sulawesi Tengah. Surabaya: Department of Architecture Faculty of Civil and Planning Engineering Institut Teknologi Sepuluh Nopember Surabaya. 